\title{
Analisis Korelasi Suhu Muka Laut dan Curah Hujan di Stasiun Meteorologi Maritim Kelas II Kendari Tahun 2005 - 2014
}

\section{Rizka Erwin Lestari ${ }^{1}$, Ambinari Rachmi Putri ${ }^{2}$, Imma Redha Nugraheni}

Sekolah Tinggi Meteorologi Klimatologi dan Geofisika

Jl. Perhubungan I No. 5, Pondok Betung, Pondok Aren, Pd. Betung, Tangerang Selatan, Kota

Tangerang Selatan, Banten 15221, Indonesia

Email : rizkaerwin26@gmail.com

\begin{abstract}
Sea surface temperature is one of many factors influencing with the weather pattern in Indonesia. This is caused by evaporation process which in turn is influenced by sea surface temperature then it will form a cloud and trigger to rainfall in the land. Additionally, it needs to be known that rainfall can affect to human activities especially in the agriculture sector. The correlation between rainfall and global sea surface temperature has been researched but the researchers have not taken into consideration yet for local sea surface temperature. Because of that, it needs to research about the correlation between rainfall and local sea surface temperature. In this paper, it uses rainfall data for synoptic observation in Maritime Meteorological Station of Kendari 2005 - 2014 and sea surface temperature data of NOAA. The analyzing used is pearson correlation analyzing to determine correlation coefficient value with lag time 1 month and hypothesis testing. Besides that, the researcher sets groups of domain sample to 8 grids. From the result of data processing, it shows that there is correlation between sea surface temperature and rainfall in Maritime Meteorological Station of

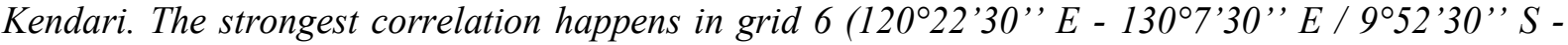

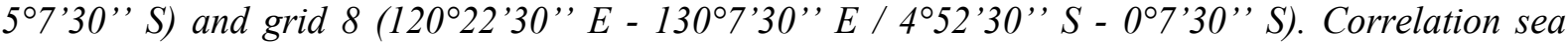
surface temperature with a lag time of 1 month shows higher correlation than without lag time. According to this result, rainfall prediction in Maritime Meteorological Station of Kendari can involve sea surface temperature in grid 6 and 8 with a lag time of 1 month.
\end{abstract}

Keywords: pearson correlation, hypothesis testing, sea surface temperature, rainfall

\begin{abstract}
Abstrak: Suhu muka laut merupakan salah satu unsur yang berpengaruh terhadap pola cuaca di Indonesia. Hal ini disebabkan karena suhu muka laut berperan penting dalam proses penguapan sehingga mempengaruhi pembentukan awan dan selanjutnya mempengaruhi curah hujan. Pada sisi lain, diketahui bahwa curah hujan berpengaruh terhadap kehidupan manusia seperti contohnya pada sektor pertanian. Hubungan antara curah hujan dengan suhu muka laut global telah banyak diteliti, tetapi untuk suhu muka laut lokal belum banyak diperhitungkan oleh para peneliti. Oleh karena itu, perlu dilakukan kajian tentang hubungan curah hujan dan suhu muka laut disekitar wilayah yang menjadi sampel. Adapun data yang digunakan pada kajian ini adalah data curah hujan Stasiun Meteorologi Maritim Kelas II Kendari tahun 2005 - 2014 dan data suhu muka laut dari NOAA. Analisis yang dilakukan adalah analisis korelasi pearson untuk menentukan nilai koefisien korelasi dengan lag waktu 1 bulan dan uji hipotesis. Selain itu peneliti mengelompokkan wilayah menjadi 8 grid. Dari hasil pengolahan data yang telah dilakukan menunjukkan bahwa terdapat hubungan antara suhu muka laut dan curah hujan di Stasiun Meteorologi Kelas II Kendari. Korelasi terkuat terjadi pada suhu muka laut di wilayah grid $6\left(120^{\circ} 22^{\prime} 30^{\prime \prime}\right.$ BT - 130 $\left.0^{\circ} 30^{\prime \prime} \mathrm{BT} / 9^{\circ} 52^{\prime} 30^{\prime \prime} \mathrm{LS}-5^{\circ} 7^{\prime} 30^{\prime \prime} \mathrm{LS}\right)$ dan

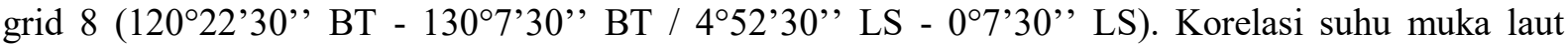
dengan lag 1 bulan menunjukkan nilai yang lebih besar daripada korelasi tanpa lag waktu. Sehingga dalam menentukan curah hujan di wilayah Stasiun Meteorologi Maritim Kelas II Kendari dapat melibatkan unsur suhu muka laut pada grid 6 dan 8 dengan lag waktu 1 bulan.
\end{abstract}

Kata kunci: korelasi pearson, uji hipotesis, suhu muka laut, curah hujan 


\section{PENDAHULUAN}

Indonesia dikenal dengan sebutan Benua Maritim Indonesia (BMI) karena lebih dari dua per tiga wilayahnya terdiri dari lautan. Keadaan ini memengaruhi berbagai aspek, di antaranya adalah aspek cuaca dan aspek iklim. Cuaca adalah kondisi sesaat atmosfer pada suatu lokasi, sedangkan iklim adalah kondisi rata-rata atmosfer pada suatu waktu dan lokasi. Menurut Edvin Aldrian dalam Buku Meteorologi Laut Indonesia, dengan bentang lautan yang luas, diyakini bahwa iklim di Indonesia sangat dipengaruhi oleh interaksi laut dan atmosfer.

Terdapat beberapa faktor yang memengaruhi pembentukan iklim di Indonesia, di antaranya adalah suhu muka laut, tekanan udara, kelembaban udara, arah dan kecepatan angin, radiasi, dan lainnya. Suhu muka laut merupakan faktor yang memengaruhi pembentukan iklim karena berperan penting dalam proses penguapan, kemudian proses penguapan akan memengaruhi pembentukan awan, dan akhirnya faktor pertumbuhan awan akan memengaruhi curah hujan.

Hubungan antara curah hujan dengan suhu muka laut global telah banyak diteliti, tetapi untuk suhu muka laut lokal (suhu muka laut dalam cakupan luasan yang lebih kecil) belum banyak diperhitungkan oleh para peneliti. Oleh karena itu, perlu dilakukan kajian tentang hubungan curah hujan dan suhu muka laut disekitar wilayah yang dijadikan sampel.

Kendari merupakan kota di Provinsi Sulawesi Tenggara yang berada pada koordinat $3^{\circ} 54^{\prime} 30^{\prime \prime}-4^{\circ} 3$ ' $11^{\prime \prime}$ LS dan $122^{\circ} 23^{\prime}-122^{\circ} 39^{\prime}$ BT. Pada kajian ini penulis menjadikan Kendari sebagai sampel karena sebelah timur Kendari berbatasan dengan Laut Kendari. Hubungan curah hujan dan suhu muka laut di sekitar wilayah Kendari perlu dianalisis agar mempermudah prakirawan cuaca dalam menentukan wilayah perairan mana saja yang harus dilibatkan dalam memprakirakan cuaca Kendari.

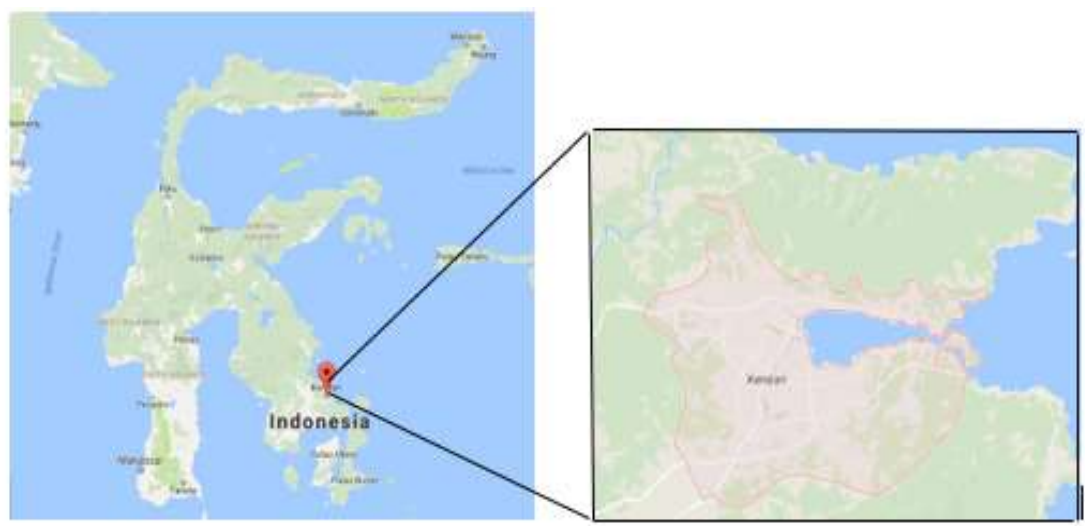

Gambar 1. Sampel Kajian (Kota Kendari)

\section{METODE PENELITIAN}

\subsection{Data}

Data yang digunakan dalam kajian ini adalah data curah hujan Stasiun Meteorologi Maritim Kelas II Kendari selama 10 tahun (2005 - 2014) dan data suhu muka laut dari NOAA selama 10 tahun $(2005$ - 2014). Data suhu muka laut dapat diakses di https://www.esrl.noaa.gov/psd/map/clim/sst.shtml.

\subsection{Metode}

Metode yang digunakan dalam kajian ini adalah analisis korelasi pearson untuk menentukan nilai koefisien korelasi dengan lag waktu 1 bulan dan uji hipotesis. Selain itu peneliti juga mengelompokkan wilayah menjadi 8 grid, guna mengetahui wilayah mana saja yang berpengaruh pada curah hujan Kendari. Berikut adalah pembagian koordinatnya: 
Tabel 1. Pembagian grid berdasarkan koordinat

\begin{tabular}{cc}
\hline Grid & Koordinat \\
\hline 1 & $110,125-120,125$ BT dan $5,375-10,125 \mathrm{LU}$ \\
2 & $120,375-130,125$ BT dan $5,375-10,125 \mathrm{LU}$ \\
3 & $110,125-120,125$ BT dan $0,125-5,125 \mathrm{LU}$ \\
4 & $120,375-130,125$ BT dan $0,125-5,125 \mathrm{LU}$ \\
5 & $110,125-120,125$ BT dan $4,875-0,125 \mathrm{LS}$ \\
6 & $120,375-130,125$ BT dan $4,875-0,125 \mathrm{LS}$ \\
7 & $110,125-120,125$ BT dan $9,875-5,125 \mathrm{LS}$ \\
8 & $120,375-130,125$ BT dan $9,875-5,125 \mathrm{LS}$ \\
\hline
\end{tabular}

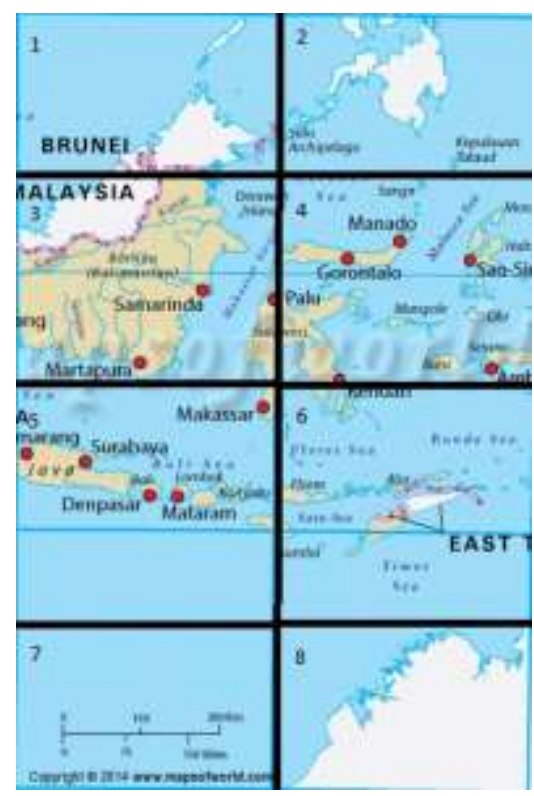

Gambar 1. Pembagian 8 grid wilayah sekitar Kendari

\section{a. Koefisien Korelasi Pearson}

Salah satu metode perhitungan koefisien korelasi yaitu metode Pearson atau koefisien korelasi Pearson. Koefisien korelasi menyatakan hubungan linear antara variable $\mathrm{X}$ dan variable $\mathrm{Y}$. Hal tersebut dirumuskan sebagai berikut :

$$
\begin{aligned}
& \mathrm{R}_{\mathrm{XY}}= \frac{n \Sigma X Y-(\Sigma X)(\Sigma Y)}{\sqrt{\left\{n \Sigma X^{2}-(\Sigma X)^{2}\right\}\left\{n \Sigma Y^{2}-(\Sigma Y)^{2}\right\}}} \\
& \text { Keterangan: } \\
& \mathrm{R}_{\mathrm{XY}}=\text { kocfisien korelasi variabel } \mathrm{X} \text { dan } \mathrm{Y} \\
& \mathrm{n}=\text { banyak pasangan variabel } \mathrm{X} \text { dan } \mathrm{Y}
\end{aligned}
$$

Gambar 2. Rumus koefisien Korelasi Pearson

Menurut Eeng Ahman dalam buku Membina Kompetensi Ekonomi menyatakan bahwa nilai $\mathrm{R}$ bisa bernilai positif dan negatif. Jika $\mathrm{R}$ positif maka 
berarti terjadi korelasi searah, sedangkan $\mathrm{R}$ negatif berarti korelasi berlawanan arah. Nilai $\mathrm{R}$ tidak mungkin satu dan tidak mungkin nol. $\mathrm{R}=1$ hanya terjadi pada korelasi dirinya sendiri misalnya korelasi $\mathrm{X}$ ke $\mathrm{X}, \mathrm{Y}$ ke $\mathrm{Y}$. Adapun $\mathrm{R}=0$ tidak pernah ada karena apapun yang ada di dunia pasti berkorelasi. Koefisien korelasi $\mathrm{R}$ merupakan bilangan murni dimana tidak memliki satuan. Untuk memudahkan dalam melakukan interpretasi mengenai kekuatan hubungan antara dua variable, berikut kritera untuk nilai koefisien korelasinya :
- 0
: Tidak ada korelasi antara dua variable
- $>0-0.25$
: Korelasi sangat lemah
- $>0.25-0.5 \quad$ : Korelasi cukup
- $>0.5-0.75 \quad$ : Korelasi kuat
- $>0.75-0.99 \quad$ : Korelasi sangat kuat
- 1
: Korelasi sempurna

(Raharja, 2007 dalam Sarwono, 2006)

\section{b. Uji hipotesis}

Untuk mengetahui hubungan kedua variable tersebut, maka dilakukan pengujian hipotesis dengan asumsi sebagai berikut:

Ho $=>$ tidak ada hubungan antara curah hujan dengan suhu muka laut

$\mathrm{H} 1=>$ ada hubungan antara curah hujan dan suhu muka laut

Menurut Adyaksa Budi Raharja (2007) dalam untuk menguji hipotesis tersebut digunakan rumus sebagai berikut :

Keterangan :

$$
\text { Thitung }=\frac{r \sqrt{n-2}}{\sqrt{1-r^{2}}}
$$

$\mathrm{T}=$ Probabilitas

$\mathrm{r}=$ Koefisien Korelasi

$\mathrm{n}=$ Jumlah periode

Untuk menarik kesimpulan dari hasil hipotesis maka perhitungan Thitung dibandingkan dengan Ttabel dengan tingkat signifikan 0.05 (5\%). Kriteria penolakan dan penerimaan hipotesis Ho adalah sebagai berikut :

1. Jika Thitung > Ttabel Ho ditolak; H1 diterima

2. Jika Thitung < Ttabel Ho diterima ; H1 ditolak 


\section{HASIL DAN PEMBAHASAN}

\subsection{Menghitung nilai Korelasi Suhu Muka Laut dan Curah Hujan}

Tabel 2. Nilai Korelasi Suhu Muka Laut dan Curah Hujan tanpa lag (kiri) dan dengan lag 1 bulan (kanan)

\begin{tabular}{ccccc}
\hline & \multicolumn{2}{c}{ TANPA LAG } & \multicolumn{2}{c}{ DENGAN LAG 1 BULAN } \\
\hline GRID & Korelasi & Interpretasi & Korelasi & Interpretasi \\
\hline GRID 1 & -0.061441 & negatif dan cukup & -0.0883 & negatif dan cukup \\
GRID 2 & -0.106146 & negatif dan cukup & -0.12735 & negatif dan cukup \\
GRID 3 & -0.112417 & negatif dan cukup & -0.13093 & negatif dan cukup \\
GRID 4 & -0.014647 & negatif dan cukup & 0.048655 & $\begin{array}{c}\text { negatif dan sangat } \\
\text { lemah }\end{array}$ \\
& & positif dan sangat & 0.491166 & positif dan cukup \\
GRID 5 & 0.236114 & lemah & & positif dan kuat \\
GRID 6 & 0.325024 & positif dan cukup & 0.56376 & positif dan kuat \\
GRID 7 & 0.331934 & positif dan cukup & 0.552588 & positif dan kuat \\
\hline
\end{tabular}

Berdasarkan perhitungan nilai korelasi antara suhu muka laut dan curah hujan di Stasiun Meteorologi Maritim Kelas II Kendari selama 10 tahun diperoleh bahwa nilai korelasi kuat berada pada Grid 6 dengan $r=0.56376$, Grid 7 dengan $r=0.552588$ dan Grid 8 dengan $r=$ 0.517971 dengan lag 1 bulan yang menunjukkan interpretasi nilai positif dan kuat $(>0.5)$. Nilai tertinggi terletak pada grid 6 dimana wilayah tersebut merupakan area terdekat dari Stasiun Meteorologi Maritim Kelas II Kendari. Untuk korelasi tanpa lag tidak menunjukkan nilai yang kuat. Pada setiap grip, apabila dibandingkan antara dengan lag 1 bulan dan tanpa lag, nilai koefisien korelasi dengan lag 1 bulan menunjukkan nilai yang lebih besar daripada tanpa lag. Hal ini disebabkan karena suhu permukaan laut mempengaruhi cuaca di daratan secara bertahap dan membutuhkan waktu yang tidak singkat, tidak dalam 1 waktu seperti unsur - unsur cuaca lain seperti angin. Sedangkan nilai - nilai negatif menunjukkan bahwa korelasi yang terjadi adalah berbanding terbalik. Pada grid 6 dengan lag 1 bulan dan grid 6 , grid 7 dan grid 8 tanpa lag suhu muka laut cukup berpengaruh terhadap curah hujan di Kendari tetapi tidak memberikan dampak yang signifikan. Pada grid $1-4$ tidak menunjukkan adanya keterkaitan antara curah hujan dan suhu muka laut di Stasiun Meteorologi Maritim Kendari Kelas II Kendari pada perhitungan nilai koefisien korelasi dnegan lag 1 bulan atau tanpa lag.

\subsection{Grafik Curah Hujan dengan Suhu Muka Laut}

Berikut merupakan grafik hubungan curah hujan dan suhu muka laut pada grid 6 , grid 7 dan grid 8 dengan lag 1 bulan dimana memiliki korelasi yang kuat positif pada kedua unsur. Berdasarkan grafik - grafik tersebut menunjukkan hubungan yang berbanding lurus antara curah hujan dan suhu muka laut, dimana pada saat curah hujan meningkat suhu muka laut juga mengalami peningkatan. Hal ini membuktikan bahwa ketika suhu muka laut hangat, pada bulan berikutnya akan terjadi hujan dengan nilai yang tinggi di wilayah daratan sekitarnya dan sebaliknya. Tetapi dalam proses pembentukan hujan, tidak hanya suhu muka laut yang berpengaruh, beberapa unsur lain berperan dalam proses terjadinya hujan di wilayah daratan. Suhu muka laut memiliki peranan yang cukup signifikan dalam proses terjadinya hujan 
karena penguapan dilautan akan dipengaruhi oleh hangatnya permukaan laut. Semakin hangat suhu permukaan laut, penguapan akan semakin besar di laut sehingga potensi pembentukan awan penghasil hujan semakin besar.

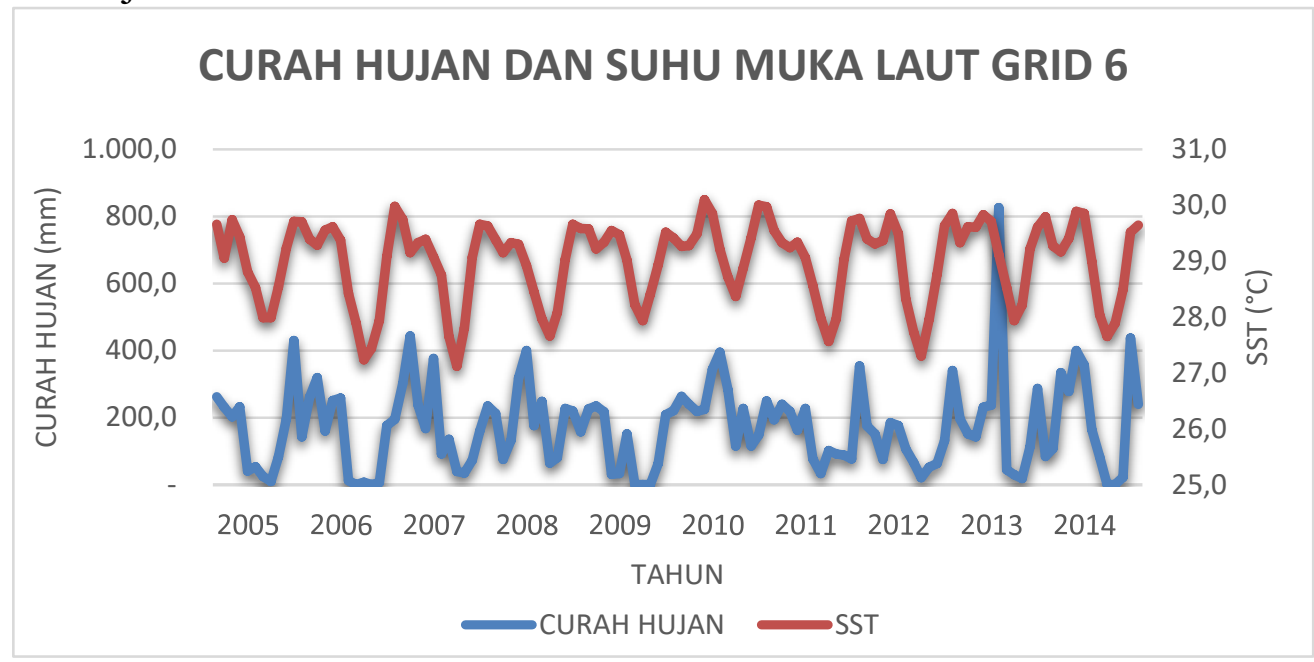

Gambar 3. Grafik hubungan curah hujan dan suhu muka laut pada grid 6 dengan lag 1 bulan

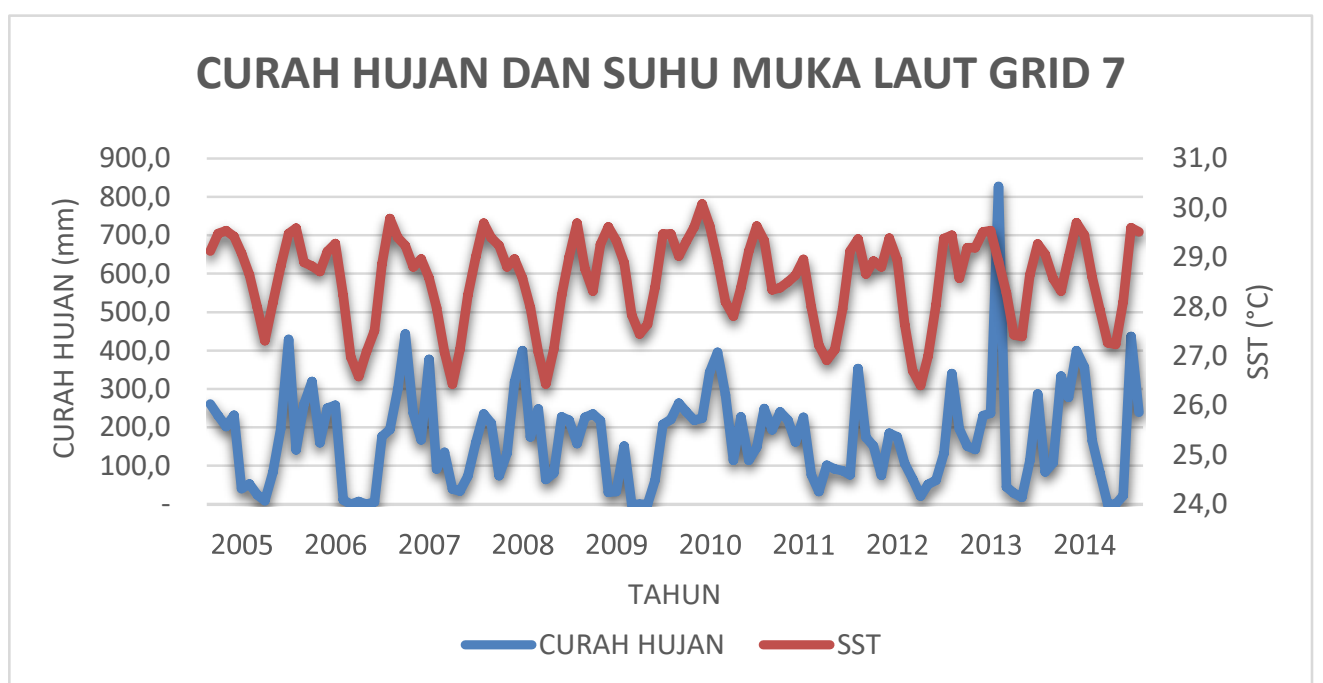

Gambar 4. Grafik hubungan curah hujan dan suhu muka laut pada grid 7 dengan lag 1 bulan 


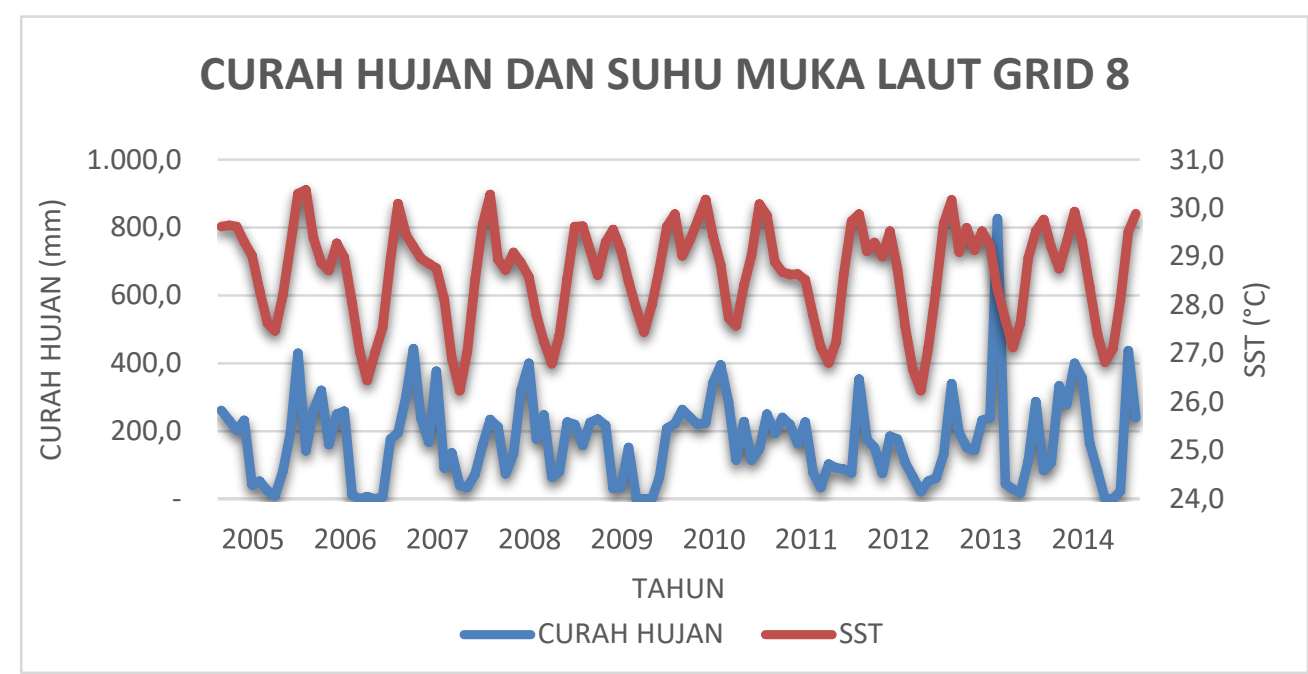

Gambar 5. Grafik hubungan curah hujan dan suhu muka laut pada grid 8 dengan lag 1 bulan

\subsection{Uji Hipotesis Nilai Koefisien Korelasi}

Dalam uji hipotesis ini bertujuan untuk mengetahui apakah korelasi tersebut signifikan atau tidak. Uji hipotesis dilakukan pada grid - grid yang memiliki nilai terkuat pada nilai koefisien korelasi yaitu grid 6, grid 7 dan grid 8. Selain itu uji hipotesis dalam penelitian ini menggunakan uji satu arah (one-tail) dengan nilai pembanding Ttabel $=1.645$ yang diperoleh dari :

$\mathrm{N}=120$

$\mathrm{Df}=\mathrm{N}-\mathrm{K}=120-2=118$

Ho $=>$ tidak ada hubungan antara curah hujan dengan suhu muka laut

$\mathrm{H} 1=>$ ada hubungan antara curah hujan dengan suhu muka laut

a. Hubungan Curah Hujan dan Suhu Muka Laut pada grid 6 dengan $r=0.56376$

Uji statistik :

$$
\text { Thitung }=0.56376 \sqrt{\frac{120-2}{1-0.56376^{2}}}
$$

$$
=7.41459
$$

Dari table distribusi $\mathrm{T}$ untuk $\mathrm{N}=120, \mathrm{df}=118, \mathrm{a}=5 \%$ dan Ttabel $=1.645$, didapat nilai Thitung sebesar 7.41459. karena nilai Thtung > Ttabel maka hasil uji hipotesis adalah Ho ditolak yang berarti ada hubungan antara suhu muka laut pada grid 6 lag 1 bulan dengan curah hujan di Stasiun Meteorologi Maritim Kelas II Kendari dimana $\mathrm{r}=0.56376$. Nilai koefisien korelasi $\left(\mathrm{r}^{2}\right)$ sebesar 0.317825 berarti sebanyak 31,7825 \% suhu muka laut pada grid 6 lag 1 bulan memberikan pengaruh terhadap curah hujan di wilayah Kendari sedangkan sisanya dipengaruhi oleh faktor - faktor lain yang tidak dijelaskan dalam penelitian ini. 
b. Hubungan Curah Hujan dan Suhu Muka Laut pada grid 7 dengan $r=0.552588$

Uji statistik :

Thitung $=0.552588 \sqrt{\frac{120-2}{1-0.552588^{2}}}$

$=7.202119$

Dengan nilai $\mathrm{N}$, df, a dan Ttabel yang sama diperoleh Thitung $=7.202119$ yang berarti Thitung lebih besar daripada Ttabel sehingga $\mathrm{H} 1$ diterima yaitu terdapat hubungan antara suhu muka laut dan curah hujan pada wilayah grid 7 lag 1 bulan dimana nilai koefisien korelasi sebesar 0.552588. apabila nilai tersebut dikuadratkan bernilai 0.305353 yang artinya sebesar $30.5353 \%$ faktor suhu muka laut berpengaruh terhadap jumlah curah hujan di Stasiun Meteorologi Maritim Kelas II Kendari. Untuk sisanya jumlah curah hujan dipengaruhi oleh faktor - faktor lain yang belum dijelaskan dalam penelitian ini.

c. Hubungan Curah Hujan dan Suhu Muka Laut pada grid 8 dengan $r=0.517971$

Uji statistik :

$$
\begin{gathered}
\text { Thitung }=0.517971 \sqrt{\frac{120-2}{1-0.517971^{2}}} \\
=6.577763
\end{gathered}
$$

Dengan nilai N, df, a dan Ttabel yang tetap sama diperoleh nilai Thitung sebesar 6.577763. Nilai tersebut menunjukkan bahwa nilai Thitung lebh besar daripada Ttabel. Sehingga dapat disimpulkan bahwa H1 diterima, yaitu terdapat korelasi antara curah hujan di Kendari dengan suhu muka laut di wilayah grid 8 dengan nilai koefisien korelasi sebesar 0.517971. Penguadratan nilai $\mathrm{r}\left(\mathrm{r}^{2}\right)$ dapat menunjukkan seberapa persen suhu muka laut pengaruhnya terhadap curah hujan. $\left(r^{2}\right)=0.268294$, menunjukkan bahwa sebesar 26.8294\% suhu muka laut pada grid 8 mempengaruhi curah hujan di Stasiun Meteorologi Maritim Kelas II Kendari sedangkan untuk persen sisanya dipengaruhi oleh faktor - faktor lain yang belum diteliti dalam penelitian ini.

\section{KESIMPULAN}

Berdasarkan hasil dan pembahasan diatas maka dapat disimpulkan bahwa :

a. Terdapat hubungan yang signifikan antara suhu muka laut pada wilayah grid 6 , grid 7 dan grid 8 dan curah hujan di Stasiun Meteorologi Maritim Kendari Kelas II Kendari

b. Korelasi terbesar terjadi pada grid 6 dengan nilai koefisien korelasi sebesar 0.56376 dengan lag 1 bulan

c. Suhu muka laut memiliki pengaruh yang lebih kuat dengan lag 1 bulan daripada tanpa lag

\section{SARAN}

Adapun saran untuk mengembangkan lebih lanjut penelitian ini agar lebih baik antara lain :

a. Sebaiknya menggunakan data series yang lebih panjang 30 tahun. Karena dalam klimatologi, waktu 30 tahun merupakan selang yang tepat untuk mencari normal suatu unsur meteorologi.

b. Perlu kajian lebih lanjut tentang faktor - faktor lain yang mempengaruhi curah hujan di Stasiun Meteorologi Maritim Kelas II Kendari sehingga dapat diketahui faktor dominan 
yang berpengaruh. Karena dalam proses terjadinya hujan dipengaruhi oleh banyak unsur atmosfer dan laut lainnya.

\section{DAFTAR PUSTAKA}

Aldrian, Edvin. (2008). Meteorologi Laut Indonesia. Badan Meteorologi Geofisika. Jakarta : Badan Meteorologi Klimatologi dan Geofisika.

NOAA. (2017, Maret 1). Daily Sea Surface Temperature. Retrieved from https://www.esrl.noaa.gov/psd/map/clim/sst.shtml.

Ahmad, Eeng dan Epi Indriani. (2007). Membina Kompetensi Ekonomi. Bandung : Grafindo Media Pratama.

Raharja, Adyaksa Budi. (2007). Hubungan Suhu Muka Laut dengan Curah Hujan di Stasiun Meteorologi Tegal Periode 1989 - 2008. Tugas Akhir : STMKG. 